\title{
Potentiality of Inducer Resistance Chemicals and Bioagents in Managing Lettuce Downy Mildew
}

\author{
Khairy Abdel-Maksoud Abada ${ }^{*}$, Amany Mohamed Farouk Attia \\ Plant Pathology Department, Faculty of Agriculture, Cairo University, Giza, Egypt \\ Email address: \\ dr_khairy_abada@yahoo.com (K. Abdel-Maksoud A.), amant farouk97@ hotmail.com (A. M. F. Attia) \\ ${ }^{*}$ Corresponding author
}

\section{To cite this article:}

Khairy Abdel-Maksoud Abada, Amany Mohamed Farouk Attia. Potentiality of Inducer Resistance Chemicals and Bioagents in Managing Lettuce Downy Mildew. American Journal of BioScience. Vol. 5, No. 1, 2017, pp. 4-12. doi: 10.11648/j.ajbio.20170501.12

Received: February 22, 2017; Accepted: March 15, 2017; Published: March 27, 2017

\begin{abstract}
The tested inducer resistance chemicals (IRCs) bion (BTH), chitosan and salicylic acid as well as the bacterial bioagents Bacillus pumilus B. subtilis, B. thuringiensis and Pseudomonas fluorescens and the fungal bioagents Trichoderma album, T. harzianum and T. viride resulted in significant reduction to the germinated sporangia (conidia) of the fungus like Bremia lactucae Regel, the causal of lettuce downy mildew. This reduction was gradually increased by increasing the used concentration. The role of the tested IRCs and bioagents on management of the disease under greenhouse was evaluated. Under greenhouse conditions, spraying of lettuce plants artificially inoculted with the causal fungus like resulted in significant reduction to the severity of the disease compared with control treatment. Moreover, the IRC bion as well as $P$. fluorescens and T. harzianum were the most efficient treatments in this regard. Two field experiments were carried out during 2016/2017 growing season under natural infection by the disease to evaluate the efficacy of spraying of lettuce plants with any of the IRC bion and the bioagents $P$. fluorescens and $T$. harzianum on plants previously soaked or not in bion just before transplanting on the severity of the disease and weight of the grown plants. Data revealed that there was significant reduction to the severity of the disease with considerable increase to the average weight of each plant compared with control treatment due to sprying of these treatments. However, the fungicide Ridomil Gold MZ was the superior treatment in reducing the disease and increasing the weight of the foliage growth of lettuce plants. In addition, spraying of the IRC bion on plants soaked in bion just before transplanting ranked the second in this regarad followed by spraying of any of the two bioagents. Considerable increase in the activity of the oxidative reductive enzymes, i.e phenylalanine ammonia lyase (PAL), peroxidase (PO) and polyphenol oxidase (PPO), due to spraying of lettuce plants with bion, the bioagents $P$. fluorescens and T. harzianum as well as the fungicide Ridomil Gold MZ compared with unsprayed plants (control).
\end{abstract}

Keywords: Lettuce, Bioagents, Downy Mildew, Inducer Resistance Chemicals, Oxidative Reductive Enzymes, Ridomil Gold MZ

\section{Introduction}

Lettuce (Lactuca sativa L.) has become an increasingly important leafy vegetable crop in many parts of the world including Egypt. Downy mildew caused by the fungus like Bremia lactucae Regel. infects lettuce and clearly the most widespread and destructive lettuce disease allover the world (Attia et al., 1990; Mieslerova et al., 2013 and Kunjeti et al., 2016). Although yield losses in the field at harvest may be substantial, downy mildew's impact is often accentuated by significant postharvest losses that occur during transit or storage. This pathogen requires cool, wet conditions for infection and disease development. The heavy canopy of densely planted lettuce retains much moisture and creates ideal conditions for infection and disease development (Crute and Gordon, 1980 and Davis, 1997). Conidia are dispersed in the air from plant to plant and field to field by winds and splashing water. The pathogen exists as distinct genetic races and shows an ability to adapt to new lettuce cultivars. The disease causes light green to yellow angular spots on the upper surfaces of leaves. White fluffy growth of the pathogen develops on the lower sides of these spots. With time these lesions turn brown and dry up. Older leaves are attacked first. 
Severely infected leaves may die. On rare occasions the pathogen can become systemic, causing dark discoloration of stem tissue. B. lactucae is a complex organism, consisting of multiple (pathotypes) races (Johnson et al., 1978).

B. lactucae is an obligate parasite, which means that it can grow and reproduce only on living plant tissue. Downy mildew is a major disease in lettuce production systems worldwide. Disease epidemics can be devastating when environmental conditions are favorable for disease development. In semiarid to arid climates disease intensity and crop loss are highly dependent on weather factors ( $\mathrm{Su}$ et al., 2004).

The fungus like $B$. lactucae is capable of infecting any lettuce growth stage from seedling to mature plant. Although downy mildew is usually most severe on the older outer leaves, the disease may become systemic over time, infecting lettuce heads internally and colonizing even the roots. Downy mildew lesions may also serve as portals for secondary invaders, such as the fungus Botrytis cinerea.

In the field the pathogen can grow and spread rapidly, resulting in widespread crop damage if environmental conditions are favorable. Initial symptoms of downy mildew consist of dull to bright yellow spots that form on the leaves of all ages. With time, these spots can enlarge and become of brown colour and dry. Close inspection of the underside of the leaf often reveals the white growth of the fungus like (conidia and conidiophores). If disease development is extensive, leaves appear curled and distorted and may take on a blighted effect as a result of numerous infection sites (Nordskog, et al., 2007).

Since the discovery of the inducer resistance chemical bion (benzothiadiazole; BTH) the use of such compounds has become an attractive alternative for controlling plant pathogens (Pajot et al., 2001).

This work aimed to evaluate the use of some IRCs and bioagents for their efficiency in management of lettuce downy mildew. The work was expanded to evaluate the effect of these materials on the activity of three oxidative reductive enzymes, i.e. peroxidase (PO), polyphenol oxidase (PPO), and phenylalanine ammonia lyase (PAL).

\section{Materials and Methods}

\subsection{Isolation, Purification and Identification of the Antagonists}

Microorganisms naturally occurred on healthy lettuce leaves surface (phylloplane) were isolated from plants collected from Dakahlia governorate using dilution plate technique. Serial dilution plate technique was used to isolate native antagonistic Trichoderma spp. on PDA medium and Bacillus spp. and Pseudomonas fluorescens on nutrient agar medium (Oedjijono and Dragar, 1993).

All the fungal cultures of Trichoderma spp. were selected and purified by hyphal tip method and then identified on the basis of cultural and microscopic morphological characters (Rifia, 1969 and Bissctt, 1991).
Also, the isolated Bacillus spp. and Pseudomonas fluorescens were purified and identified using the description of Parry et al. (1983) and Holt and Krieg (1984).

\subsection{Effect of the Tested Inducer Resistance Chemicals (IRCs) and Bioagents on Conidiospores Germination of B. lactucae}

The effect of the different IRCs on the germinated conidiospores of B. lactucae was carried out in vitro. The concentrations of $0.0,5,10,20$ and $40 \mathrm{mM}$ of the IRCs, i.e. bion (benzothiadiazole; BTH), chitosan (cellulose with the hydroxyl at position $\mathrm{C}_{2}$ substituted with an acetamido group) and salicylic acid (monohydroxybenzoic acid) were prepared depending on their molecular weight.

The antagonistic effect of the isolated bacteria, i.e. B. pumilus, B. subtilis, B. thuringiensis and Pseudomonas fluorescens and fungi, i.e. T. album, T. harzianum and T. viride on the germination of the conidiospores of the fungus like B. lactucae was assessed in vitro. Flasks $(250 \mathrm{ml}$.) containing nutrient medium were inoculated with loops of the culture of any of the tested bacteria and incubated at $28 \pm 2$ for $48 \mathrm{~h}$. to grow. Also, Trichoderma spp. were grown on gliotoxin fermentation medium (GFM) as described by Brain and Hemming (1945) for 7 days. Twenty ml. of sterile water were added to each Petri-dish and growth (spores and mycelium) was gently crushed by sterilized camel brush and collected in sterile $500 \mathrm{ml}$ conical flask. The collected growth was filter through 3 layer of cheese cloth.

The bacterial and fungal filtrate was sterilized using 0.25 $\mu \mathrm{m}$ syringe filter. The concentrations of $0.0,20,40,60$ and $80 \%$ were prepared from the sterilized filtrate for each bioagent using sterilized water.

Freshly conidiospores of the pathogen were added to each concentration of the tested bacterial and fungal bioagents as well as the antioxidants. One $\mathrm{m} 1$. of conidial suspension was placed on each sterilized slide, borne on two glass rods in a sterilized Petri-dish (two slides in each Petri-dish) containing a piece of wetted cotton by sterilized distilled water to provide high relative humidity. The same was made for a spore suspension put in distilled sterilized water only as control treatment. Preparations were incubated in darkness at $18 \pm 1^{\circ} \mathrm{C}$ for 24 hour. Five Petri dishes for each treatment were used as replicates. One drop from lacto- phenol cotton blue stain was added at the time of slide examination to fix and kill the germinated conidia. The percentages of conidial germination were counted in a total of 100 conidiospore in each glass slide. The germinated conidia were counted and the mean was calculated and recorded for each treatment.

\subsection{Greenhouse Experiment}

The effect of the IRCs bion, chitosan and salicylic acid as well as the bioagents, i.e. B. subtilis, B. pumilus,, $B$. thuringiensis, P. fluorescens, T. album, T. harzianum and $T$. viride on the severity of lettuce downy mildew caused by the fungus like $B$. lactucae was carried out using artificial 
inoculation under greenhouse conditions in order to select the most efficient IRC and bioagents to assess their efficiency in management of the disease under field conditions.

Plastic pots $(30 \mathrm{~cm}$ in diameter) containing disinfested Nile silt soil with $5 \%$ formalin were transplanted with lettuce transplants (cv. Balady). Transplants of 35 days age were divided into two parts. The first part was soaked for two hours just before transplanting in $20 \mathrm{mM}$ of bion and the second part in irrigation water for the same period then transplanted. Three transplants were transplanted in each pot and irrigated. Five pots were used for each treatment. The grown plants (aged 3 weeks) were sprayed with the tested IRCs $(20 \mathrm{mM})$ and the bioagents $\left(1 \times 10^{6} \mathrm{cfu}\right.$ for the bacteria and $1 \times 10^{6}$ spore for the fungi / $\mathrm{ml}$ water), five days before the artificial inoculation with the conidial suspension $\left(1 \times 10^{3} / \mathrm{ml}\right.$ water $)$ of the causal pathogen (Attia et al., 1990). The plants re-sprayed with the tested treatments at the previous rates 10 days after the inoculation with the tested pathogen. Plants sprayed with conidial suspension of the causal pathogen were left as control treatment. Two ml. of Tween-20 were added to each $10 \mathrm{ml}$. of the sprayed preparations of bion, bioagents, Ridomil Gold MZ and water. The grown plants were irrigated when it was necessary and fertilized by the Crystalon compounded fertilizer (one g. for each pot), three weeks after transplanting and each week for three times.

The severity of the disease was assessed 15 days after each spray by the tested IRCs and bioagents and the averages were recorded using the devised scale (0-3) by Lebeda et al. (2008).

\subsection{Field Experiments}

A piece of land located at Aga country, Dakahlia governorate (clay soil), near Nile River was prepared for transplanting lettuce transplants (c.v Balady) in each experiment. The land was divided into plots of $\left(10.5 \mathrm{~m}^{2} ; 6\right.$ rows of $3 \mathrm{~m}$. long x $3.5 \mathrm{~m}$ width). Transplants of 35 days age were divided into two parts. The first part was soaked for two hours just before transplanting in $20 \mathrm{mM}$ of bion and the second part in irrigation water for the same period then transplanted in the presence of water irrigation on the two sides of the rows at $20 \mathrm{~cm}$. apart. Two experiments were carried out. The first one was transplanted on October 25, 2016 and the second on December 1, 2016. The plants were left two grow under natural infection, where the environmental conditions in this location are suitable for sever infection by lettuce downy mildew. All agricultural practices, i.e. irrigation, weeds and pests control as well as fertilization were applied according to the standard recommendations of Min. of Agric. and Land Reclamation.

The tested IRC bion $(20 \mathrm{mM})$ and the bioagents $P$. fluorescens $\left(1 \times 10^{6} \mathrm{cfu} / \mathrm{ml}\right.$ water and T. harzianum $\left(1 \times 10^{6}\right.$ spore / $\mathrm{ml}$ water) as well as the fungicide Ridomil Gold MZ (Mefenoxam + Mancozeb) as positive control ( $2 \mathrm{~g} / \mathrm{ml}$ water) were sprayed at the first appearance of downy mildew symptoms by the causal pathogen and 10 days later. Unsprayed lettuce plants with any materials were left as control treatment. Twenty $\mathrm{ml}$. of Tween-20 were added to each $100 \mathrm{ml}$. of the sprayed preparations of bion, bioagents, Ridomil Gold MZ and water. Three replicates were used for each treatment. Disease severity of downy mildew was assessed in each experiment using the devised scale (0-3) by Lebeda et al. (2008) and the averages were recorded. In the same time, the harvested (cut-off) plants weighed and the averages were recorded at the end of the experiment ( 75 days).

\subsection{Disease Assessment}

Disease assessment was assessed using 0-3 scale to estimate the severity of the infection as follows:

$0=$ No visible symptoms,

$1=$ Low disease progress (DP) with either occurrence of chlorotic spots on infected leaves associated with sparse or no visible sporulation of the causal pathogen B. lactucae,

$2=$ Medium DP with either medium occurrence of chlorotic or necrotic leaf spots with sporulation of the causal pathogen $B$. lactucae covering up to $50 \%$ of leaves and plants and

3 = High DP with either the majority of leaves and plants almost completely covered by chlorotic or necrotic spots with profuse sporulation of the causal pathogen.

Both artificially (10 ramdam outer leaves from each treatment were examined) and naturally (100 ramdam outer leaves from each treatment were examined) infected plants were carefully examined to estimate the severity of the infection by downy mildew using the following formula:

Disease severity $\%=£(n \times v) / 3$ N X 100

Where:

$\mathrm{n}=$ Number of infected leaves in each category.

$\mathrm{v}=$ Numerical values of each category.

$\mathrm{N}=$ Total number of the infected leaves.

\subsection{Estimation the Activity of Three Oxidative-Reductive Enzymes}

The activity of the three oxidative-reductive enzymes, i.e. phenylalanine ammonia lyase (PAL), peroxidase (PO) and polyphenol oxidase (PPO) was measured in leaves of lettuce plants treated with the different treatments as shown in Table (6). Samples were taken two weeks after the treatment with the different treatments for enzymes assay. One gram of lettuce leaves sample was homogenized with $2 \mathrm{ml}$ of $0.1 \mathrm{M}$ sodium phosphate buffer ( $\mathrm{pH}$ 7.0) in ice bath for enzyme assays. The homogenates were then centrifuged at $10,000 \mathrm{~g}$ for $10 \mathrm{~min}$. Supernatants were used to analyze the defenserelated enzymes (PAL, PO and PPO) activities.

\subsubsection{Estimation of PAL Activity}

The activity of phenylalanine ammonia lyase (PAL) was determined according to the described method of Burrell and Rees (1974). The mixture contained 0.03 M L-phenylalanine and $0.2 \mathrm{ml}$ enzyme extract in a total $2.5 \mathrm{ml}$ of sodium borate buffer ( $\mathrm{pH} 8.8$ ). This reaction mixture was kept in a water bath at $37^{\circ} \mathrm{C}$ for $1 \mathrm{~h}$, and $0.5 \mathrm{ml}$ of $1 \mathrm{M}$ (trichloroacetic acid) TCA was added. The amount of trans-cinnamic acid formed from L-phenylalanine was measured spectrophotometrically 
at $290 \mathrm{~nm}$. Enzyme activity was expressed as microgram of trans-cinnamic acid $\mathrm{h}^{-1} \mathrm{mg}^{-1}$ protein.

\subsubsection{Estimation of PO Activity}

In order to estimate peroxidase activity (PO), $50 \mu$ l of enzyme extract was added to $2.85 \mathrm{ml}$ of $0.1 \mathrm{M}$ phosphate buffer ( $\mathrm{pH} 7.0$ ) and mixed with $0.05 \mathrm{ml}$ of $20 \mathrm{mM}$ guaiacol reagent (Vetter et al., 1958). The reaction was started by the addition of $0.02 \mathrm{ml}$ of 40 $\mathrm{mM}$ hydrogen peroxide to the mixture. Rate of increase in absorbance at $470 \mathrm{~nm}$ was measured over $1 \mathrm{~min}$. One unit of enzyme activity was defined by the change in absorbance of 0.01 for $1 \mathrm{~g}$ fresh weight per minute.

\subsubsection{Estimation of PPO Activity}

Polyphenol oxidase (PPO) activity was determined according to the method proposed by Mayer et al. (1965). The mixture was containing $200 \mu \mathrm{l}$ enzyme extract and 1.5 $\mathrm{ml}$ of $0.01 \mathrm{M}$ catechol. Activity was expressed as changes in absorbance at $495 \mathrm{~nm} \cdot \mathrm{min}^{-1} \mathrm{mg}^{-1}$ protein.

\subsection{Statistical Analysis}

Data were statistically analyzed using the standard procedures for complete randomize block as well as split and split split designs as mentioned by Snedecor and Cochran (1967). The averages were compared at 5\% level using least significant differences (L. S. D) according to Fisher (1948).

\section{Results}

\subsection{Isolation, Purification and Identification of the Antagonists}

Isolation trials of the bacterial and fungal bioagents from healthy lettuce leaves surface (phylloplane) collected from Dakahlia governorate yielded many bacterial and fungal isolates. The isolates of Bacillus and Trichoderma genera were selected and the bacterium Pseudomonas fluorescens was incidentally isolated. The isolated bacteria of genus Bacillus were purified and identified as: B. pumilus, B. subtilis and B. thuringiensis. The isolates of genus Trichoderma were purified and identified as: T. album, T. harzianum and T. viride.

\subsection{Effect of the Tested Inducer Resistance Chemicals (IRCs) and Bioagents on Conidiospores Germination of B. Lactucae}

Table (1) indicates that the tested IRCs, i.e. bion, chitosan and salicylic acid caused significant reduction to the germinated conidia compared with control treatment. Bion was the most efficient one, being 38.8\% conidial germination and caused complete inhibition to the germinated conidia at the concentration of $20 \mathrm{mM}$ followed by salicylic acid, being $53.0 \%$ conidial germination then chitosan, being $54.7 \%$ conidial germination. The inhibitory effect on the conidial germination was gradually increased by increasing of the IRCs concentration. Control treatment recorded $93.4 \%$ conidial germination.

Data presented in Table (2) reveal that the tested bacterial bioagents, i.e. B. pumilus, B. subtilis, B. thuringiensis and $P$. fluorescens resulted in significant reduction to the germinated conidia of the causal fungus like compared with the control treatment. This reduction was gradually increased by increasing of the concentration of the culture filtrate of the tested bioagents from 20 to $80 \%$, being 76.5, 40.5, 15.8 and $0.2 \%$ conidial germination, respectively. Both P. fluorescens and $T$. harzianum caused complete inhibition to the germinated conidiospores at the concentration of $60 \%$. Meanwhile, B. subtilis, B. thuringiensis and T. viride caused complete inhibition to the germinated conidiospores at the concentration of $80 \%$. However, both B. pumilus and $T$. album failed to caused complete inhibition to the germinated conidiospores at the concentration of $80 \%$. Control treatment recorded $94.2 \%$ conidial germination. In addition, the bacterium $P$. fluorescens was the most efficient one, being 39.6 conidial germination followed by the fungus $T$. harzianum, being $40.5 \%$ conidial germination.

Table 1. Effect of three ICRs on conidial germination of the causal fungus like. B. lactucae, 24 hour after incubation at $18 \pm 1^{\circ} \mathrm{C}$.

\begin{tabular}{lccllll}
\hline \multirow{2}{*}{ IRCs } & \multicolumn{3}{l}{$\begin{array}{l}\text { Average percentage of germinated conidia* } \\
\text { at (\%) }\end{array}$} & \multicolumn{1}{c}{ Mean } \\
\cline { 2 - 6 } & $\mathbf{0 . 0}$ & $\mathbf{5}$ & $\mathbf{1 0}$ & $\mathbf{2 0}$ & $\mathbf{4 0}$ & \\
\hline Bion & 93.4 & 70.2 & 30.8 & 0.0 & 0.0 & 38.8 \\
Chitosan & 93.4 & 82.2 & 58.4 & 29.8 & 10.0 & 54.7 \\
Salicylic acid & 93.4 & 80.6 & 55.8 & 27.4 & 8.0 & 53.0 \\
Mean & 93.4 & 77.7 & 21.7 & 19.1 & 3.0 & ---- \\
\hline
\end{tabular}

* Conidial germination at zero time $=1.8 \%$.

L. S. D. at $5 \%$ for:

$\operatorname{IRCs}(I)=2.3$, Concentrations $(C)=2.7$ and $\mathrm{I} x \mathrm{C}=3.4$.

Table 2. Effect of some bacterial and fungal bioagents on conidial germination of B. lactucae, 24 hour after incubation at $18 \pm 1{ }^{\circ} \mathrm{C}$.

\begin{tabular}{lllllll}
\hline \multirow{3}{*}{ Bioagentss } & \multicolumn{9}{l}{$\begin{array}{l}\text { Average percentage of germinated } \\
\text { conidia* at (\%) }\end{array}$} & \multirow{2}{*}{ Mean } \\
\cline { 2 - 6 } & $\mathbf{0 . 0}$ & $\mathbf{2 0}$ & $\mathbf{4 0}$ & $\mathbf{6 0}$ & $\mathbf{8 0}$ & \\
\hline B. pumilus & 94.2 & 78.6 & 45.6 & 23.4 & 10.0 & 47.1 \\
B. subtilis & 94.2 & 76.6 & 43.8 & 21.0 & 0.0 & 50.4 \\
B. thuringiensis & 94.2 & 75.2 & 42.8 & 20.0 & 0.0 & 46.4 \\
P. fluorescens & 94.2 & 73.6 & 30.4 & 0.0 & 0.0 & 39.6 \\
T. album & 94.2 & 79.2 & 47.8 & 27.8 & 12.0 & 52.2 \\
T. harzianum & 94.2 & 74.6 & 33.6 & 0.0 & 0.0 & 40.5 \\
T. viride & 94.2 & 77.6 & 39.8 & 18.4 & 0.0 & 46.0 \\
Mean & 94.2 & 76.5 & 40.5 & 15.8 & 0.2 & ---- \\
\hline
\end{tabular}

*Conidial germination at zero time $=1.4 \%$.

L. S. D. at $5 \%$ for:

Bioagents $(\mathrm{B})=2.1$, Concentrations $(\mathrm{C})=2.5$ and $\mathrm{B} \times \mathrm{C}=3.5$.

\subsection{Greenhouse Experiment}

Data tabulated in Table (3) reveal that all the tested IRCs and bioagents resulted in significant reduction to the severity of lettuce downy mildew compared with control treatment. However, the treatment of soaking lettuce transplants in the IRC bion just before transplanting and spraying them two times by any of the tested IRCs and bioagents was more efficient in reducing the severity of the disease $(2.9 \%)$ compared with spraying of the tested IRCs and bioagents on plants soaked in water (un-soaked in the IRC bion), being 
$4.2 \%$. In addition, the most efficient treatment in this regard was the IRC bion $(2.2 \%)$ followed by both salicylic acid and P. fluorescens $(2.8 \%)$ then $T$. harzianum $(2.9 \%)$. Therefore, they were used in the field experiments to managing the disease under the natural infection. Meanwhile, both $B$. pumilus and T. album were the lowest efficient treatments (3.9\%) followed by chitosan $(3.5 \%)$ then $T$. viride $(3.4 \%)$. Plants sprayed with any of $B$. subtilis and B. thuringiensis recorded $3.2 \%$ disease severity. Unsprayed plants of the control plants recorded $18.5 \%$ disease severity.

Table 3. Effect of spraying of some inducer resistance chemicals and bioagents on the severity of lettuce downy mildew under greenhouse conditions.

\begin{tabular}{lccc}
\hline & \multicolumn{2}{c}{ \% Disease severity of plants } & \multirow{2}{*}{ Mean } \\
\cline { 2 - 3 } Treatments & Un-soaked & Soaked in & \\
\cline { 2 - 3 } & in BTH & BTH & \\
\hline IRCs & ---- & ---- & 2.2 \\
Bion & 3.2 & 1.1 & 3.5 \\
Chitosan & 4.0 & 2.1 & 2.8 \\
Salicylic acid & 3.8 & 1.8 & --- \\
Bioagents & ---- & ---- & 3.9 \\
B. pumilus & 5.0 & 2.7 & 3.2 \\
B. subtilis & 4.2 & 2.2 & 3.2 \\
B. thuringiensis & 4.0 & 2.3 & 2.8 \\
P. Fluorescens & 3.6 & 2.0 & 3.9 \\
T. album & 5.0 & 2.7 & 2.9 \\
T. harzianum & 3.7 & 2.1 & 3.4 \\
T. viride & 4.2 & 2.6 & 18.5 \\
Control & 26.3 & 10.7 & --- \\
\hline Mean & 4.2 & 2.9 & \\
\hline
\end{tabular}

L. S. D. at $5 \%$ for:
$\operatorname{IRCs}(I)=2.3$, Soaking $(\mathrm{S})=0.9$ and $\mathrm{I} \times 3=2.4$.

\subsection{Field Experiments}

Table (4) shows that the tested IRC bion, the two bioagents $P$. fluorescens and T. harzianum and the fungicide Ridomil Gold MZ resulted in significant reduction to the severity of lettuce downy mildew compared with the control treatment. The severity of the disease on the plants of the second experiments was significantly higher than on the plants of the first experiment, being 8.1 and $6.7 \%$, respectively. However, the treatment of soaking lettuce transplants in the IRC bion just before transplanting and spraying them two times by any of the tested IRC bion, the two bioagents and the fungicide Ridomil Gold MZ was more efficient in reducing the severity of the disease $(5.0 \%)$ compared with spraying them on plants un-soaked in the IRC bion $(9.8 \%)$. However, the fungicide Ridomil Gold MZ was the superior treatment in both experiments, being 0.3 and $1.2 \%$ disease severity, respectively followed by spraying of the IRC bion (1.3 and $3.6 \%$ disease severity, respectively) then spraying of $P$. fluorescens (3.5 and 3.9\% disease severity, respectively) and T. harzianum (4.8 and 5,1\% disease severity, respectively). Control treatment recorded 22.9 and $26.1 \%$ disease severity, respectively.

Results shown in Table (5) show that the reduction in the severity of lettuce downy mildew was significantly reflected on the weight of the grown plants. In general, soaking lettuce transplants in the IRC bion was more efficient in increasing the foliage growth than of un-soaked transplants in the IRC bion (soaked in water only), being 593.1 and $538.4 \mathrm{~g} /$ plant, on the average, respectively. In addition, the fungicide Ridomil Gold MZ was the superior treatment in both experiments, being 625.0 and $615.5 \mathrm{~g} /$ plant, on the average, respectively.

Table 4. Effect of spraying the IRC bion and the bioagents P. fluorescens and T. harzianum in comparison with the fungicide Ridomil Gold MZ on the severity of lettuce downy mildew, field experiments at Dakahlia governorate during 2016/2017 growing seasons.

\begin{tabular}{|c|c|c|c|c|c|}
\hline \multirow{2}{*}{ Treatments } & \multirow{2}{*}{ Experiment number } & \multicolumn{2}{|c|}{$\%$ Disease severity of plants } & \multirow{2}{*}{ Mean } & \multirow{2}{*}{ General mean } \\
\hline & & Un-soaked in BTH & Soaked in BTH & & \\
\hline \multirow{2}{*}{ Bion } & First & 1.8 & 0.8 & 1.3 & \multirow{2}{*}{2.5} \\
\hline & Second & 4.1 & 3.0 & 3.6 & \\
\hline \multirow{2}{*}{ P. fluorescens } & First & 4.6 & 3.5 & 4.1 & \multirow{2}{*}{4.3} \\
\hline & Second & 5.0 & 3.9 & 4.5 & \\
\hline \multirow{2}{*}{ T. harzianum } & First & 5.3 & 4.3 & 4.8 & \multirow{2}{*}{5.0} \\
\hline & Second & 5.5 & 4.6 & 5.1 & \\
\hline \multirow{2}{*}{ Ridomil Gold MZ } & First & 0.6 & 0.0 & 0.3 & \multirow{2}{*}{0.7} \\
\hline & Second & 1.4 & 1.0 & 1.2 & \\
\hline \multirow{2}{*}{ Control } & First & 31.9 & 13.8 & 22.9 & \multirow{2}{*}{24.5} \\
\hline & Second & 37.9 & 14.3 & 26.1 & \\
\hline \multirow{2}{*}{ Mean } & First & 8.8 & 4.5 & 6.7 & \multirow{2}{*}{----- } \\
\hline & Second & 10.8 & 5.4 & 8.1 & \\
\hline General mean & ----- & 9.8 & 5.0 & ----- & ----- \\
\hline
\end{tabular}

L. S. D. at $5 \%$ for:

Treatments $(\mathrm{T})=2.1$, Experiment number $(\mathrm{E})=1.1$, Soaking $(\mathrm{S})=3.7, \mathrm{TxE}=2.3, \mathrm{TxS}=1.7, \mathrm{ExS}=1.9$ and $\mathrm{T} \times \mathrm{ExS}=2.1$.

\subsection{Changes in the Activity of Oxidative-Reductive Enzymes}

Data presented in Table (6) show the changes in the activity of oxidative-reductive enzymes, i.e. phenylalanine ammonia lyase (PAL), peroxidase (PO) and polyphenol oxidase (PPO) due to spraying of lettuce plants with the IRC 
bion (BTH) and the two bioagents, i.e. P. fluorescens and T. harzianum as well as the fungicide Ridomil Gold $\mathrm{MZ}$ compared with the control treatment.

In general, results indicate that there was considerable increase in the activity of the three enzymes, i.e. PAL, PO and PPO in the leaves of all sprayed treatments compared with control treatment. Plants sprayed with BTH recorded the highest activity of the three enzymes followed by those sprayed with $P$. fluorescens then $T$. harzianum and Ridomil Gold MZ, being 1.469, 1.422, 1.275 and 1.184, respectively. Meanwhile, untreated leaves (control) recorded the lowest activity, being 0.770 .

Table 5. Effect of spraying of the IRCs bion and the bioagents P. fluorescens and T. harzianum in comparison with the fungicide Ridomil Gold MZ on the average weight of lettuce plants (g), field experiments at Dakahlia governorate during 2016/2017 growing season.

\begin{tabular}{|c|c|c|c|c|c|}
\hline \multirow{2}{*}{ Treatments } & \multirow{2}{*}{ Experiment number } & \multicolumn{2}{|c|}{ Average weight of lettuce plants (g) } & \multirow{2}{*}{ Mean } & \multirow{2}{*}{ General mean } \\
\hline & & Un-soaked in BTH & Soaked in BTH & & \\
\hline \multirow{2}{*}{ Bion } & First & 581 & 640 & 610.5 & \multirow{2}{*}{601.0} \\
\hline & Second & 562 & 621 & 591.5 & \\
\hline \multirow{2}{*}{ P. fluorescens } & First & 564 & 610 & 587.0 & \multirow{2}{*}{581.0} \\
\hline & Second & 545 & 605 & 575.0 & \\
\hline \multirow{2}{*}{ T. harzianum } & First & 555 & 604 & 579.5 & \multirow{2}{*}{572.0} \\
\hline & Second & 535 & 594 & 564.5 & \\
\hline \multirow{2}{*}{ Ridomil Gold MZ } & First & 590 & 660 & 625.0 & \multirow{2}{*}{620.3} \\
\hline & Second & 581 & 650 & 615.5 & \\
\hline \multirow{2}{*}{ Control } & First & 441 & 483 & 462.0 & \multirow{2}{*}{454.5} \\
\hline & Second & 430 & 464 & 447.0 & \\
\hline \multirow{2}{*}{ Mean } & First & 546.2 & 599.4 & 572.8 & \multirow{2}{*}{---- } \\
\hline & Second & 530.6 & 586.8 & 558.7 & \\
\hline General mean & ---- & 538.4 & 593.1 & ---- & ---- \\
\hline
\end{tabular}

L. S. D. at $5 \%$ for:

Treatments $(T)=10.8$, Experiment number $(E)=8.7$, Soakin $(S)=11.43, \mathrm{TxE}=12.1, \mathrm{TxS}=9.5, \operatorname{ExS}=10.7$ and $\mathrm{T} x \operatorname{ExS}=9.5$.

Table 6. Effect of spraying of lettuce plants with BTH and the tested bioagents P. fluorescens and T. harzianum in comparison with the fungicide Ridomil Gold $M Z$ on the activity of three oxidative reductive enzymes.

\begin{tabular}{lccc}
\hline \multirow{2}{*}{ Treatments } & \multicolumn{3}{c}{ Activity of enzymes * } \\
\cline { 2 - 4 } & Phenylalanine ammonia lyase (PAL) & Peroxidase (PO) & Polyphenol oxidase (PPO) \\
\hline Bion (BTH) & 0.484 & 0.428 & 0.557 \\
P. fluorescens & 0.472 & 0.415 & 0.535 \\
T. harzianum & 0.445 & 0.401 & 0.429 \\
Ridomil Gold MZ & 0.408 & 0.392 & 1.422 \\
Control & 0.246 & 0.209 & 0.384 \\
\hline
\end{tabular}

*Expressed as absorption after $30 \mathrm{sec}$. at appropriate wave length and the activity of PAL, PO and PPO at zero time were $0.225,0.200$ and 0.203 , respectively.

\section{Discussion}

The fungus like Bremia lactucae Regel causes one of the most devastating diseases of lettuce worldwide. This obligate pathogen is capable of infecting any lettuce growth stage from seedling to mature plant, and sporulates mainly on the lower side of leaves. It attacks not only the members of the Lactuca genus, but also more than 150 species and about 40 genera of the family Asteraceae (Crute and Davis, 1977). In spite of its broad host range, individual isolate of $B$. lactucae is highly hostspecific and mostly limited to the same host plant species or genus (Attia et al., 1990; Lebeda et al., 2002; Mieslerova et al., 2013 and Kunjueti et al., 2016). In addition, it is closely related to cultivated lettuce and is considered as its ancestor (de Vries, 1997 and Lebeda et al., 2007).

With increasing public awareness of the environmental implications of the use of large quantities of fungicides in agricultural practices, alternative strategies for the control of plant disease are being sought (Ellis et al., 1999). Biological control using antagonistic microbes alone, or as supplements to minimize the use of chemicals in a system of integrated plant disease management, has become more important in recent years.

Isolation trials of the bacterial and fungal bioagents from healthy lettuce leaves surface (phylloplane) collected from Dakahlia governorate yielded many bacterial and fungal isolates, i.e. B. pumilus, B. subtilis and B. thuringiensis, Pseudomonas fluorescens T. album, T. harzianum and T. viride.

All the tested IRCs bion, chitosan and salicylic acid as well as the isolated bioagents resulted in significant reduction to the germinated conidia of the causal fungus compared with the control treatment. This reduction was gradually increased by increasing the concentration of these treatments. In addition, the conidia of the causal fungus failed to germinate at $20 \mathrm{mM}$ of bion and at the concentration of $60 \%$ for P. fluorescens and $T$. harzianum.

Under greenhouse conditions, spraying of lettuce plants artificially inoculted with the causal fungus like resulted in significant reduction to the severity of the disease compared with control treatment. Moreover, the IRC bion as well as $P$. fluorescens and $T$. harzianum were the most efficient treatments in this regard. Moreover, the treatment of soaking lettuce transplants in the IRC bion (BTH) just before 
transplanting and spraying them two times by any of the tested IRC bion and the two bioagents was more efficient in reducing the severity of the disease compared with spraying them on plants of un-soaked transplants in the IRC bion.

Abada and Eid (2014) found that in vitro experiment the tested IRCs, i.e. bion, chitosan, salicylic acid and zinc sulphate and the bioagents, i.e. Bacillus polymexa, B. subtilis and Pseudomonas fluorescens resulted in significant reduction to the germinated sporangia of the fungus like Pseudperonospora cubensis as well as the severity of cantaloupe downy mildew and increased plant length and foliage fresh weight in pot experiment compared with control treatment.

It has been found from the two field experiments that the tested IRC bion, the two bioagents P. fluorescens and $T$. harzianum and the fungicide Ridomil Gold $\mathrm{MZ}$ resulted in significant reduction to the severity of lettuce downy mildew compared with control treatment. The severity of the disease on the plants of the second experiments was significantly higher than on plants of the first experiment. This increase may be due to, to some what, the prevalent of low temperature and high humidity during the growth of the plants of the second experiment than that prevalent in the first experiment. Su et al. (2004) mentioned that B. lactucae prefers low temperatures $\left(10-15^{\circ} \mathrm{C}\right)$ and higher relative humidity $(95-100 \%)$ for sporulation and infection process. Furthermore, B. lactucae also has specific demands for light (Nordskog et al., 2007). Also, the treatment of soaking lettuce transplants in the IRC bion (BTH) just before transplanting and spraying them two times by any of the tested IRC bion, the two bioagents and the fungicide Ridomil Gold MZ was more efficient in reducing the severity of the disease compared with spraying them on plants of un-soaked transplants in the IRC bion. Furthermore, the fungicide Ridomil Gold MZ was the superior treatment in both experiments followed by spraying of the IRC bion then spraying of $P$. fluorescens and T. harzianum. Similar results were obtained by Abada and Abdel-Malek (2011) on pea downy mildew and Abada and Eid (2014) on cantaloupe doawny mildew.

BTH is a systemic acquired resistance elicitor, which reduces many fungal diseases. It has been previously shown that pea rust infection can be reduced by exogenous applications of systemic acquired resistance elicitors such as BTH (Barilli et al., 2015). This protection is known to be related with the induction of the phenol pathway but the particular metabolites involved have not been determined yet. This suggests fungal growth impairment by both direct toxic effect as well as plant cell wall reinforcement.

Kessmann et al. (1994) reported that the mechanism of systemic acquired resistance is apparently multifaceted, likely resulting in stable broad spectrum disease control and they could be used preventatively to bolster general plant health, resulting in long lasting protection. Iriti and Faoro (2003) reported that bion was used to induce resistance in bean against rust caused by Uromyces appendiculatus. Histochemical and cytochemical investigations showed that BTH causes hydrogen peroxide $\left(\mathrm{H}_{2} \mathrm{O}_{2}\right)$ accumulation in the treated tissues. $\mathrm{H}_{2} \mathrm{O}_{2}$ deposits were localized in situ for the first time in the apoplast of the leaf epidermis. No cell death was detected at BTH concentrations below the phytotoxicity threshold, suggesting that acquired resistance against bean rust is mainly related to the enhanced activity of anionic peroxidases, promoted by $\mathrm{H}_{2} \mathrm{O}_{2}$ accumulation, thereby leading to cell wall strengthening. This hypothesis is also supported by the long induction phase required to establish complete resistance.

Biological control has emerged as an alternative and most promising means of the management of plant pathogens. The earlier studies revealed that antimicrobial metabolites produced by Trichoderma spp. are effective against a wide range of phytopathogenic fungi. In addition, Trichoderma spp. are known to control pathogens either indirectly by competing for nutrients and space, modifying the environmental conditions, or promoting plant growth and enhancing plant defensive mechanisms and antibiosis, or directly by inhibition of growth and sporulation of the pathogen mechanisms such as mycoparasitism and enzyme production (Junid et al., 2013 and Bhattacharjee and Dey, 2014). The inhibitory activity of the tested bioagent Trichoderma on the development of germ tube of the pathogen could be explained by the ability of Trichoderma spp. to produce volatile substances that are able to limit and even stop the development of the pathogen. Also it is found that there is large variety of volatile secondary metabolites produced by Trichoderma strains such as ethylene, carbon dioxide, hydrogen cyanide, aldehydes and ketones, which play an important role in controlling the plant pathogens (Junid et al., 2013 and Bhattacharjee and Dey, 2014).

Ramamoorthy et al. (2001) reported that the bioactivity of $P$. fluorescens might be due to produces different types of antibiotics including active 2, 4 diacetyl- phloroglucinole (2, 4 DAPB), which control diseases and/or due to that $P$. fluorescens has several methods to control the disease such as production of antifungal compounds including siderophre production, nutrient competition and the induction of systemic resistance. Sarnigute et al. (1995) and Meena et al. (2006) mentioned that the reduction in the infection by that plant pathogens and the increase in the plant length and fresh weight of the treated plants might be due to P. fluorescens produces indole acetic acid as a growth regulator as well as some antibiotic, i.e. pyrrolnitrin, pyoluterin and 2, 4 diacetyl phloroglucino.

The obtained results demonstrated that the reduction in the severity of lettuce downy mildew was significantly reflected on the weight of the grown plants. In general, soaking lettuce transplants in the IRC bion just before transplanting was more efficient in increasing the foliage growth of lettuce plants than of un-soaked transplants in the IRC bion (soaked in water only).In addition, the fungicide Ridomil Gold MZ was the superior treatment in both experiment followed by spraying of the IRC bion then spraying of $P$. fluorescens and T. harzianum. Control treatment recorded the lowest weight of the grown plants. However, although the increase in the weight of lecttue plants due to managing downy mildew was 
not of high figures, but is very important due to the green colour of the leaves of such plants is very attractive and acceptable by the consumer compared with the shape of the leaves of the infected plants. Also, the dead plochs give a chance for growing many saprophytes on these dead plochs.

The obtained data revealed that there was considerable increase in the activity of the three enzymes, i.e. PAL, PO and PPO in the leaves of all sprayed treatments compared with control treatment. Plants sprayed with BTH recorded the highest activity of the three enzymes followed by those sprayed with $P$. fluorescens then $T$. harzianum and Ridomil Gold MZ. Meanwhile, untreated leaves (control) recorded the lowest activity.

Reuveni et al.(1991) mentioned that the association between variation for pre-infection peroxidase activity and levels of field resistance-susceptibility to downy mildew (Bremia lactucae) was investigated in lettuce (Lactuca sativa) cultivars, accessions of $L$. serriola (prickly lettuce), segregating $F_{2}$ populations and selected $F_{3}$ families from a cross between field resistant and susceptible lettuce cultivars. A trend was apparent in this series of experiments indicating that one component of field resistance could be related to a high level of peroxidase activity prior to infection. The data suggest that in breeding programmes there could be merit in imposing primary selection for high peroxidase activity prior to field selection for resistance.

The interaction between the pathogen and the host plant induces some changes in cell metabolism; primarily activity of enzymes, particularly phenylalanine ammonia lyase (PAL), peroxidase (POD), polyphenol oxidase (PPO), lipoxygenase (LOX), superoxide dismutase (SOD) and $\beta-1,3$ glucanase (Thipyapong and Steffens, 1992 and Vanitha et al., 2009). PAL is the primary enzyme in the phenylpropanoid pathway, which leads to the conversion of L-phenylalanine to transcinnamic acid with the elimination of ammonia. It is the key enzyme in the synthesis of several defense-related secondary compounds such as phenols and lignin (Gerasimova et al., 2005). PPO is a nuclear encoded enzyme that catalyzes the oxygendependent oxidation of phenols to quinones. PPO levels in a plant increase when a plant is wounded or infected (Vanitha et al., 2009).

Melo et al. (2006) declared that the participation of an endogenous supply of phenol compound in the plant disease resistance is dependent upon active phenol oxidase system. El-Khallal (2007) reported that both polyphenol oxidase and peroxidase are important in the defense mechanism against pathogens, through their role in the oxidation of phenolic compounds to quinines, causing increasing in antimicrobial activity. Therefore, they may be directly involved in stopping pathogen development; accelerating the cellular death of cells close to the infection site, preventing the advance of infection and/or by generating a toxic environment which will inhibit the growth of the pathogen inside the cells. Moreover, Morkunas and Gemerek (2007) reported that peroxidase enzyme oxidizes the phenolics to more fungal toxic compounds such as quinines, which inhibit both spore germination and fungal growth. Also, peroxidase was found to be participate in the synthesis of lignin.

\section{Concolusion}

This study showed that there are promising antagonistic species of bacteria and fungi prevalent on lettuce leaves, which could be exploited for the control of lettuce downy mildew in combination with the IRC bion (BTH). Based on the present investigation a new strategy could be developed for managing of lettuce downy mildew in vivo to produce healthy plants free from fungicides residue.

\section{References}

[1] Abada, K. A and Abdel-Malek, Gehan, A. M.(2011).The role of some systemic fungicides and resistance inducing chemicals on controlling pea downy mildew. Zagazig J. Agric. Res., 38 (2): 319-337.

[2] Abada, K. A. and Eid, Kh. E. (2014). A Protocol suggested for manage-ment of cantaloupe downy mildew. Am. J. of Life Sci., 2 (6-2): 1-10.

[3] Attia, M. F.: Abada K. A. and Mohamed, I. A. (1990).Studies on Bremia lactucae Regel in A. R. Egypt. $6^{\text {th }}$ Cong. of Phytopathol, 5-7 March, Cairo, Egypt., 403-420.

[4] Barilli, E.; Diego, R.; Carmine, A.; Antonio, E. and Prats, Elena. (2015). BTH and BABA induce resistance in pea against rust (Uromyces pisi) involving differential phytoalexin accumulation. Planta 242 (5): 1095-1106. doi: 10.1007/s 00425- 015-2339-8.

[5] Bhattacharjee, R. and Dey, U. (2014). An overview of fungal and bacterial biopesticides to control plant pathogens / diseases. Afr. J. of Microbiol. Res., 8 (17): 1749-1762.

[6] Bissett, J. (1991). A revision of the genus Trichoderma. W: Infragenic classification. Can. J. Bot., 69: 2357-2317.

[7] Brain, P. W. and Hemming, H. G. (1945). Gliotoxin a fungistatic metabolic product of Trichoderma viride. Ann. Appl. Biol., 32: 214-220.

[8] Burrell, M. M. and Rees, T. A. (1974). Metabolism of phenylalanine and tyrosine in rice leaves infected by Pyricularia oryzae. Physiol. Plant Pathol, 4: 497-508.

[9] Crute, I. R. and Davis, A. A. (1977). Specificity of Bremia luctucae from Luctucus. Trans. Br. mycol. Sot., 69: 405-410.

[10] Crute, I. R. and Gordon, P. L. (1980). Downy mildew of lettuce; Integrated control. Rep. Nat. Veg. Res. Stn. for 1979: 75.

[11] Davis, E. M. (1997). Compendium of lettuce diseases.The American Phytopathological Society, 79 pp.

[12] De Vries, I. M. (1997): Origin and domestication of Lactuca sativa L. Genetic Resources and Crop Evolution, 44: 165-174.

[13] El- Khallal, Samia M. (2007). Induction and modulation of resistance in tomato plants against Fusarium wilt disease by bioagent fungi (arbuscular mycorrhiza) and/or hormonal elicitors (jasmonic acid \& salicylic acid): 2-Changes in the antioxidant enzymes, phenolic compounds and pathogen related- proteins. Aust. J. of Basic and Appl. Scis., 1 (4): 717-732. 
[14] Fisher, R. A. (1948). Statistical Methods $6^{\text {th }}$ ed. Iowa State Univ. Press, Ames, Iowa, USA.

[15] Ellis, R. J.; Timms-Wilson, T. M.; Beringer, J. E.; Rhodes, D.; Renwick, A.; Stevenson, L. and Bailey, M. J. (1999). Ecological basis for biocontrol of damping-off disease by Pseudomonas fluorescens 54/96. J Appl. Microbiol, 87: 454-463.

[16] Gerasimova, N. G.; Pridvorova, S. M. and Ozeretskovskaya O. L. (2005). Role of L-phenylalanine ammonia lyase in the induced resistance and susceptibility of potato plants. Appl. Biochemis. and Microbiol., 41: 103-105.

[17] Holt, J. G. and Krieg, N. R. (1984). Bergey's Manual of Systematic Bacteriology. Williams \& Wilkins, Baltimore, USA.

[18] Johnson, A. G.; Laxton, S. A.; Crute, I. R.; Gordon, P. L.and Norwood, J. M. (1978). Furtherwork on the genetics of race specific resistance in lettuce (Lactuca sutiva) to downy mildew (Bremia luctucae). Ann. Appl. Biol., 89: 257-264.

[19] Junid, J. M.; Dar, N. A.; Baht, T. A.; Baht, A. H. and Baht, M. A. (2013). Commercial biocontrol agents and their mechanism of action in the management of plant pathogens. Inter. J. of Modern Plant and Animal Scis., 1 (2): 39-57.

[20] Iriti, M. and Faoro, F (2003). Benzothiadiazole (BTH): induces cell-death independent resistance in Phaseolus vulgaris against Uromyces appendiculatus. J. of Phytopathol., 151 (3): 171-180.

[21] Kessmann, H.: Sataub, T.; Hofmann, C.; Meatzke, T. and Herzog, J. (1994). Induction of systemic acquired disease resistance in plants by chemicals. Ann. Rev. Phytopathol., 32: 439-459.

[22] Kunjeti, S. G.; Anchieta, A.; Martin, F. N.; Choi, Y. J.; Thines, M.; Michelmore, R. W.; Koike, S. T.; Tsuchida, C.; Mahaffee, W.; Subbarao, K. V. and Klosterman, S. J. (2016). Detection and quantification of Bremia lactucae by spore trapping and quantitative PCR. Phytopathology, 106 (11): 1426-1437.

[23] Lebeda. A.; Pink, D. A. C. and Astley, D. (2002). Aspects of the interactions between wild Lactuca spp. and related genera and lettuce downy mildew (Bremia lactucae). In: SpencerPhillips P. T. N., Gisi U., Lebeda A. (eds): Advances in Downy Mildew Research. Kluwer Academic Publishers, Dordrecht: 85-117.

[24] Lebeda, A.; Ryder, E. J.; Grube, R.; Dolezalova, I. and Kristkova, E. (2007). Lettuce (Asteraceae; Lactuca spp.). In: Singh R. J. (eds): Genetic Resources, Chromosome Engineering, and Crop Improvement. Vol. 3. Vegetable Crops. CRC Press, Taylor and Francis Group, Boca Raton: 377-472.

[25] Lebeda, A.; Petrzelova, I. and Maryska, Z. (2008). Structure and variation in the wild-plant pathosystem: Lactuca serriolaBremia lactucae. Eur. J. of Plant Pathol., 122: 127-146.

[26] Mayer, A. M.; Harel E. and Shaul R. B. (1965). Assay of catechol oxidase a critical comparison of methods. Phytochemistry, 5: 783-789.

[27] Melo, G. A.; Shimizu, M. M. and Mazzafera, P. (2006). Polyphenol oxidase activity in coffee leaves and its role in resistance against the coffee leaf miner and coffee leaf rust.Phytochemistry, 67: 277-285.

[28] Meena, B.; Marimuthu, T. and Velazhahan, R. (2006). Role of fluoroscent pseudomonas in plant growth promotion and biological control of late leaf spot of groundnut. Acta Phythopatho-logica et Entomologica Hungarica, 41 (3-4): 203-212.

[29] Mieslerova, B.; Lebeda, A.; Petrelova, I. and Korbelova, P.(2013). Incidence of lettuce downy mildew (Bremia lactucae) and powdery mildew (Golovinomyces cichoracearum) in natural populations of Prickly lettuce (Lactuca serriola). Plant Protec. Sci., 49: S24-S32.

[30] Morkunas, I. and Gemerek, J. (2007). The possible involvement of peroxidase in defense of yellow lupine embryo axes against Fusarium oxysporum. J. Plant Physiol., 164: 497-506.

[31] Nordskog, B.; Gadoury, D. M.; Seem, R. C. and Hermansen A. (2007). Impact of diurnal periodicity, temperature and light on sporulation of Bremia lactucae. Phytopathology, 97: 979-986.

[32] Oedjijono, M. A. L. and Dragar, C. (1993). Isolation of bacteria antagonistic to a range of plant pathogenic fungi. Soil Biol. Biochemis., 25: 247-250.

[33] Pajot, E,; Le Corre, D. and Silue, D. (2001).Phytogard and DL- $\beta$-amino butyric acid (BABA) induce resistance to downy mildew (Bremia Lactucae) in lettuce (Lactuca sativa L). Eur. J. of Plant Pathol., 107 (9): 861-869.

[34] Parry, J. M.; Turnbull, P. C. B. and Gibson, J. R. (1983). A colour atlas of Bacillus species, Wolfe Medical Publications Ltd. 390-396.

[35] Ramamoorthy, V.; Viswanathan, R.; Raguchander, T.; Pkakasam, V. and Samivappan, R. (2001). Induction of systemic resistance by plant growth promoting rhizobacteria in crop plants against pests and diseases. Crop Protec., 20 (1): $1-11$.

[36] Reuveni, R.; Shimoni, M. and Crute, I. R. (1991). An association between high peroxidase activity in lettuce (Lactuca sativa) and field resistance to downy mildew (Bremia lactucae). J. Phytopathol., 132: 312-318.

[37] Rifai, M. A. (1969). A revision of the genus Trichoderma. Mycological Papers, 116: 1-56.

[38] Sarnigute, A. J.; Kraus, Lenkels, M. D.; Muchlchen, A. M. and Loper, J. E. (1995). The sigma factor affects antibiotic production and biological control activity of Pseudomonas fluorescens PF-5. Proc. Watl. Acad. Sci., USA, 92: 12255-12259.

[39] Snedecor, G. W. and Cochran, W. G. (1967). Statistical Methods. $6^{\text {th }}$ Ed. Iowa State Univ. Press, Ames, Iowa, USA.

[40] Su, H.; van Bruggen, A. H. C.; Subbarao, K. V. and Scherm, H. (2004).Sporulation of Bremia lactucae affected by temperature, relative humidity, and wind in controlled conditions. Phytopathology, 94: 396-401.

[41] Thipyapong, P. and Steffens, J. C. (1992).Tomato polyphenol oxidase. Plant Physiol., 100: 1885-1890.

[42] Vanitha, S. C.; Niranjana, S. R. and Umesha, S. (2009). Role of phenylalanine ammonia lyase and polyphenol oxidase in host resistance to bacterial wilt of tomato. J. Phytopathol., 157: 552-557.

[43] Vetter, S. D. (1958). Quantitative determination of peroxidaese in sweet corn. Agric. and Food Chemis. 6 (1): 39-41. 